\title{
Agronomic performance and beer quality assessment of twenty hop cultivars grown in Central Italy
}

\author{
Francesco Rossini,, Paolo Loreti, ${ }^{1}$ Maria Elena Provenzano, ${ }^{1}$ Diana De Santis, ${ }^{2}$ \\ Roberto Ruggeri ${ }^{1}$ \\ 'Department of Agriculture and Forestry Science; ${ }^{2}$ Department for Innovation in Biological,
Agro-food and Forest Systems, University of Tuscia, Viterbo, Italy
}

\begin{abstract}
Hop market and beer industry have always been of secondary relevance in Italy as compared to grape and wine sector. Hence, hop cultivars and the information for growing hops have been generated almost entirely from the major hop production countries. Identifying cultivars that perform well in Mediterranean environments is therefore essential to successfully start hop cultivation and breeding activity in this new growing region. To evaluate the intraspecific diversity of hop in Central Italy, 20 female hop genotypes with different origin were screened during three growing seasons (2013-2015) in an experimental hop yard. Cones yield, plant height and crop phenology were evaluated to determine which cultivars were best suited to the Mediterranean climate. Moreover, given the rising interest for the development of local beers with distinguishing aroma, a sensory analysis was performed and beers flavoured with locally produced and imported cones were compared. A significant diversity among cultivars was found for all parameters investigated. The results indicated that weather condition during flowering and development of cones markedly affected yield and plant height. Cones yield was negatively correlated
\end{abstract}

Correspondence: Roberto Ruggeri, Department of Agriculture and Forestry Science (DAFNE), University of Tuscia, via San Camillo de Lellis, 01100 Viterbo, Italy.

E-mail: r.ruggeri@unitus.it

Key words: Humulus lupulus; thermal time; cone yield; sensory analysis.

Acknowledgements: we would like to thank field assistants Mr. Albino Balletti and Mr. Nazareno Foderini for their help with data collection and hop yard set up, and Mr. Silvio Sbrilli for weather data collection and supply.

Conflict of interest: the authors declare no potential conflict of interest.

Conference presentation: SIA XLIV Congress, Bologna, 2015.

Received for publication: 19 January 2016.

Revision received: 25 March 2016.

Accepted for publication: 25 March 2016.

(C) Copyright F. Rossini et al., 2016

Licensee PAGEPress, Italy

Italian Journal of Agronomy 2016; 11:746

doi:10.4081/ija.2016.746

This article is distributed under the terms of the Creative Commons Attribution Noncommercial License (by-nc 4.0) which permits any noncommercial use, distribution, and reproduction in any medium, provided the original author(s) and source are credited. with thermal time $(\mathrm{r}=-0.5, \mathrm{P}<0.05)$ to harvest and positively with plant height $(\mathrm{r}=0.56, \mathrm{P}<0.05)$. Cascade, Hallertauer Magnum, Hersbrucker Spat and Yeoman showed the best adaptability to the Mediterranean growing conditions as they were the top-performing cultivars across the three years. Sensory analysis evidenced the importance of cultivar selection as determining factor for flavouring properties of beers. In general, results showed that the origin of cones strongly affected the mouth feel of beers. More complex and appreciated aroma profiles were identified for beers flavoured with local cones than those hopped with commercial products.

\section{Introduction}

Hop (Humulus lupulus L.) is a dioecious perennial climbing plant mainly cultivated for its female inflorescence (known as cone but formally strobilus), rich in alpha acids and other secondary metabolites. Commercial production of hop is generally limited to regions between $35^{\circ}$ and $55^{\circ}$ latitude in both hemispheres, as the plant is sensitive to chilling and day-length for optimal growth and flowering (Haunold, 1980; Mahaffee and Pethybridge, 2009).

Hop has a long history of utilisation in pharmaceutical industry, where it was principally used for its anti-anxiety purposes (Shishehgar et al., 2012). It became also widely appreciated as a preservative and clarifying component in the beer-brewing process and even more to provide flavour, bitterness, aroma, and antimicrobial properties to beer (Zanoli and Zavatti, 2008; Mongelli et al., 2015).

The genus Humulus native of North-temperate areas, consists of three species: $H$. lupulus, $H$. japonicus and H. yunnanensis (Small, 1978; Murakami et al., 2006). H. lupulus has been classified into a number of taxonomic varieties distributed in different countries (Small, 1978): var. lupulus for European wild hops and cultivars, var. cordifolius for Japanese wild hops, and var. neomexicanus, pubescens and lupuloides, for North American hops.

Hop breeding started with clonal selections from adapted wild hops and gradually achieved remarkable results in improving yield and quality traits using European landraces (Fuggle, Goldings, UK; Saazer, Czech Republic; Tettnanger, Spalter, Hallertauer Mittlefruh, Germany), because they provide the flavours preferred by brewers (Patzak et al., 2010).

For the brewing market it is possible to make a distinction between aroma hops varieties, grown primarily for their aroma properties, and alpha hops, grown mainly for their bittering effect (Zepp et al., 1995; McAdam et al., 2014). The main compounds responsible of hop bittering are alpha acids, which are influenced by both genetic and environmental factors (Pavlovic et al., 2012; Fandiño et al., 2015).

Many studies on hop are focused on the heritability of marketable traits controlled by quantitative trait locus genes and the characterisation of varieties by molecular DNA methods as those are more reliable 
and not affected by growing conditions and environmental factors in respect to metabolites profiling and chemical analysis (Patzak et al., 2010; McAdam et al., 2014; Mongelli et al., 2015). Hop breeding programs have been mostly focused on improving alpha acids content and disease resistance (Cerenak et al., 2009; Henning et al., 2011), while public hop research is lacking in many aspects of basic agronomy (Turner et al., 2011). Besides, there are very little information about hop modern varieties cultivation and their agronomical performances and requirements, especially in Mediterranean environs (Mongelli et al., 2015). Within this context, it has to be noticed that, even though wild hop plants normally grow in the whole Italian peninsula (Pignatti, 1982), no systematic studies on environmental adaptability of hop cultivars were conducted in Italy till now. This was probably due to some objective difficulties in conducting open field research on hop plants: installing high trellis system, waiting at least three years before having plants ready for data collection, picking by hand each cone to determine yield performance etc. Moreover, in our country, hop market and beer industry have always been of secondary relevance as compared to grape and wine, so that hop cultivation has never been widespread in Italy and domestic demand for hop has been entirely satisfied by foreign countries. Nevertheless, beer production sensibly increased from 11.5 million hL (1997) to 13.5 million hL (2014) and its consumption raised from 14.5 to 17.7 million hL as well (Assobirra, 2009, 2014). Furthermore, the beer market still has a great potential as the rising number of microbreweries and brewpubs suggests (Assobirra, 2014). These new entities are increasingly interested in producing local beers using local raw materials, including hop.

This reveals a need for testing genotypes not only with original phytochemical traits but also characterised by good environmental adaptability and yield performance, to be introduced in cultivation or to be included in breeding programs, even more in that Countries or areas which are not typically hop producers.

The aim of this study is to identify, among a selection of 20 commercial cultivars, those suited to the Mediterranean climate with potential in terms of agronomic performance and brewing quality.

\section{Materials and methods}

\section{Plant materials}

Twenty female hop cultivars from USA, England, Germany, Czech Republic and New Zealand were used. These genotypes were selected among the hop cultivars most used to flavour beers in the Italian brewing industry.

Their maturity timelines and brewing use are reported in Table 1.

\section{Location, experimental design and plant growth}

The trial was carried out during three years, from 2013 to 2015 , at the experimental farm of the University of Tuscia, Central Italy $\left(42^{\circ} 26^{\prime}\right.$ $\mathrm{N}, 12^{\circ} 04^{\prime} \mathrm{E}$, altitude $310 \mathrm{~m}$ a.s.l.). Hop rhizomes were planted on April 13,2011 in a silt clay soil. Hops were grown on a standard high trellis system where the wires were supported $8 \mathrm{~m}$ above the ground and plants spaced with $1.8 \mathrm{~m}$ between rows and $1.5 \mathrm{~m}$ in the row. The experimental design was a randomised complete block with three replicates for each cultivar (five plant plots). Weeds, pests and pathogens were chemically controlled to avoid any biological stress. Fertilisation was 80 $\mathrm{kg} \mathrm{ha}^{-1}$ year-1 $\mathrm{P}_{2} \mathrm{O}_{5}$ and $150 \mathrm{~kg} \mathrm{ha}^{-1}$ year-1 $\mathrm{K}_{2} \mathrm{O}$, while $\mathrm{N}$ was split in two rates of 50 and $50 \mathrm{~kg} \mathrm{ha}^{-1}$ for spring (April) and late spring (May-June) treatments. Hop yard was irrigated when needed with a drip irrigation system. The total water amount was $200 \mathrm{~mm}$ in $2013,55 \mathrm{~mm}$ in 2014 and $350 \mathrm{~mm}$ in 2015 .

\section{Meteorological data}

Climate data records were obtained from the University's meteorological station located a few hundred meters away from the hop yard and are shown in Figure 1.

In 2013, during the growing period (March-September), the average $\mathrm{T}_{\min }$ and $\mathrm{T}_{\max }$ were 11.9 and $24.8^{\circ} \mathrm{C}$, respectively. In 2014 , average $\mathrm{T}_{\min }$ and $\mathrm{T}_{\max }$ were lower, with values of 11.6 and $23.8^{\circ} \mathrm{C}$, respectively. Finally, 2015 average $\mathrm{T}_{\min }$ and $\mathrm{T}_{\max }$ reached the highest values of 12.7 and $25.7^{\circ} \mathrm{C}$. Particularly, $\mathrm{T}_{\max }$ in June and July 2013 reached values of

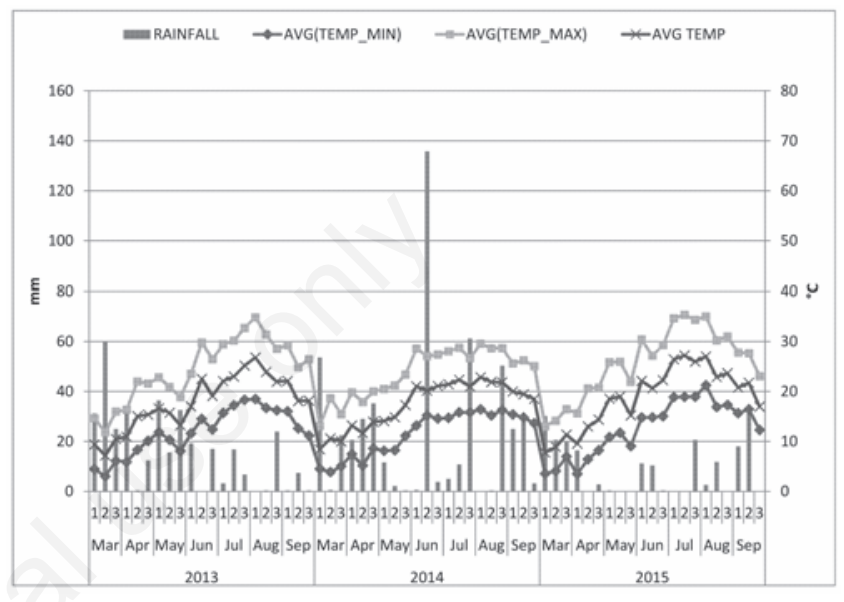

Figure 1. Decadal mean maximum, mean minimum and average air temperature and precipitation in Viterbo during 2013-2015 growing seasons.

Table 1. List of hops varieties used for the experiment, their maturity timelines, brewing use and origin.

\begin{tabular}{lccc}
\hline Variety & Maturity timelines & Brewing use & Origin \\
Cascade & M & Dual purpose & US \\
Challenger & L & Dual purpose & UK \\
\hline Columbus & M to L & Dual purpose & US \\
East Kent Golding & M & Aroma & UK \\
\hline Fuggle & E to M & Aroma & UK \\
Hallertau Mittelfruh & E to M & Aroma & Germany \\
\hline Hallertauer Aroma & E & Aroma & New Zealand \\
Hallertauer Bitter & E to M & Bittering & Germany \\
\hline Hallertauer Magnum & L & Bittering & Germany \\
Hallertauer Taurus & L & Bittering & Germany \\
\hline Hallertauer Tradition & E to M & Aroma & Germany \\
Hersbrucker Spat & L & Aroma & Germany \\
\hline Northern Brewer & E to M & Dual purpose & UK \\
Omega & M & Bittering & UK \\
\hline Perle & M to L & Dual purpose & Germany \\
Pheonix & E & Dual purpose & UK \\
\hline Redsell's Eastwell & M to L & Dual purpose & UK \\
Tettnanger & E & Aroma & Germany \\
\hline Whitbread Golding Variety & E to M & Dual purpose & UK \\
Yeoman & E & Bittering & UK \\
\hline & & &
\end{tabular}

M, medium; L, late; E, early. 
26.6 and $30.8^{\circ} \mathrm{C}$, respectively, 27.7 and $27.8^{\circ} \mathrm{C}$ in $2014,28.9$ and $34.8^{\circ} \mathrm{C}$ in 2015. Similarly, rainfall amount in 2014 was higher than in 2013 and 2015, reaching in the period March-September about $500 \mathrm{~mm}$ vs 340 and $200 \mathrm{~mm}$ recorded during the 2013 and 2015 crop season, respectively.

\section{Field measurements}

Hops were grown under the same conditions and compared for phenology, productivity, growth and aromatic traits.

The phenological surveys were performed every week during the biological cycle using the $B B C H$ centesimal scale (Meier, 2001), and growth stages (GS) of emergence of first shoots (GS 0: Sprouting 09), full flowering (GS 6: Flowering 65), beginning of cones formation (GS 7: Development of cones 71) and cones ripe for picking (GS 8: Maturity of cones 89) were recorded.

Temperature data and phenological records were used to estimate the hop thermal time following the formula:

$$
\mathrm{GDD}=\sum_{\text {days }}\left(\frac{T_{\max }+T_{\min }}{2}\right)-T_{\text {base }}
$$

where growing degree days (GDD) is thermal time (or heat sum) accumulated before a given stage is completed, ${ }^{\circ} \mathrm{C}$-day $\left({ }^{\circ} \mathrm{Cd}\right)$; $\mathrm{T}_{\max }$ is the daily average maximum temperature; $\mathrm{T}_{\min }$ is the daily average minimum temperature; $\mathrm{T}_{\text {base }}$ is the temperature below which the plant growth does not progress (McMaster and Wilhelm, 1997). According to Srečec et al. (2008), in the present study the $\mathrm{T}_{\text {base }}$ used for GDD calculation was $5^{\circ} \mathrm{C}$. Degree days were summed beginning from $1^{\text {st }}$ of January, since there were not cold periods of 5 or more consecutive days with a growing degree day value lower or equal to 0 and a 5 -days average temperature less than or equal to $-2{ }^{\circ} \mathrm{C}$ (Johnson, 1991).

We used plant height as an indicator of plant vigour and adaptability. Hops height was measured at harvest time after plants were cut off.

At harvest, hop cones from each plot were collected and weighed. Considering the plants density, yield was reported as tons per hectare of dry matter cones. Dry weight was obtained in a oven with forced ventilation at $55^{\circ} \mathrm{C}$ until constant weight. Afterward, samples were vacuum-packed and stored at $-20^{\circ} \mathrm{C}$ until they were used for brewing process.

\section{Sensory evaluation}

Thanks to a local brewery, in 2013 hops whole cones locally harvested and commercial ones were used to make beer through the dry hopping process using a standard first wort hop with cv Amarillo equal to every beer produced. As control was used beer obtained just from the standard first wort without the other aroma treatments. According to local production and commercial availability, it was possible to produce a total of 14 beers. In particular, the control was compared with beers dryhopped with cones of the following cultivars: Cascade, East Kent Golding (EKG), Fuggle, H. Tradition and H. Spat using both local and commercial cones; Columbus, Omega and Yeoman using only local cones.

The sensory analysis was performed according to ISO 8589:2007, ISO 5492:2008, ISO 13299:2016 and the beer flavour wheel of the American Society of Brewing Chemists (ASBC) (ISO, 2007, 2008; ASBC, 2009; ISO, 2016).

After a preliminary screening session, the 14 coded beer samples analysed in this study were further evaluated using a descriptive sensory techniques in a purpose-built sensory laboratory.

The sensory panel consisted of 12 assessors, 3 women and 9 men (aged from 23 to 57), recruited from a pool of experienced in sensory analysis (staff and students) of the Food Technology Lab of the University of Tuscia.

For the sensory descriptive analysis method, the judges were trained using commercial beers to familiarise with the product, in order to recognise sensory differences and generate descriptive attributes.

Training of panellists included four sessions held over four weeks and involved attribute generation, discussion, consensus, scale use and agreement on reference standards. The panellists were asked to generate a vocabulary and compare samples for aroma, flavour, mouthfeel and aftertaste. A standardised system of beer aroma terminology was presented during the initial training sessions to assist with vocabulary development.

A total of ten attributes were selected by consensus to describe the beer samples, taking into account only flavour characters of major relevance for brewing. Six descriptors (sweet, bitter, salty, acid, astringent and pungent) belong to the taste family including the mouthfeel/palate sub-class, and four (floral, fruity, grassy and spicy) belong to odour class of flavour attributes.

The final step of training consisted in a scoring booth session whereby samples of beer were presented to the panel in individual booths, under controlled lighting and temperature, together with filtered water for palate cleansing.

Six formal evaluation sessions were undertaken and judges recorded the intensity of each attribute by scoring according to a 1-9 scale.

Each beer sample was poured immediately before the beginning of each session and served $\left(30 \mathrm{~mL}\right.$ at $\left.22^{\circ} \mathrm{C}\right)$ in coded blue oil tasting glasses to avoid biases due to beer colour differences (International Olive Oil Council, 2007). Tasting glasses were covered with a lid (watch glass) and each beer was evaluated by each panellist in triplicate.

\section{Statistical analysis}

To investigate the effects of genetic and/or year factor and interactions between them on recorded variables, an analysis of variance (ANOVA) was performed using the statistical $\mathrm{R}$ software ( $\mathrm{R}$ Development Core Team, 2006). When significant factors and/or interactions between them ( $\mathrm{F}$ values) were observed, a pairwise analysis was carried out by the Fisher's least significant difference (LSD) test, both at the 0.95 and 0.99 confidence level. A simple correlation matrix was constructed for field measurements collected during the study and each pair of variables was correlated by calculating Pearson's correlation coefficients ( $\mathrm{r}$ value).

\section{Results}

\section{Crop phenology}

Significant difference in plant phenology was detected among cultivars during the trial (Table 2). Averaged over years, Cascade, Phoenix and Yeoman were consistently registered as early cultivars in each phenological stage, while Perle, EKG and H. Spat as the late ones.

\section{Sprouting (growth stage $=09$ )}

The difference between the earliest and latest cultivar for shoots emergence date was $159^{\circ} \mathrm{Cd}$. Columbus and Cascade were the earliest varieties with a thermal time need of just 236.4 and $243.0^{\circ} \mathrm{Cd}$ respectively. Cultivars showing precocity in this stage were also Whitbread Golding variety (WGV) and H. Magnum with 251.9 and $258.3^{\circ} \mathrm{Cd}$ respectively. On the contrary, Northern Brewer (NB) and EKG ranked as late sprouting genotypes with 375.3 and $377.9^{\circ} \mathrm{Cd}$, respectively, just before Perle which was the last cultivar to get shoots emergence with $395.4^{\circ} \mathrm{Cd}$. Omega, Fuggle and $H$. Taurus performed as medium sprout- 
ing varieties showing a need of GDD accumulation of 315.3, 320.8 and $321.3^{\circ} \mathrm{Cd}$, respectively.

\section{Flowering (growth stage $=65$ )}

The difference between the earliest and latest cultivar for full flowering date was $364.6^{\circ} \mathrm{Cd}$. $N B$ was the first flowering cultivar with a need of just $653.8^{\circ} \mathrm{Cd}$. Other cultivars showing earliness in this stage were Tettnager, Yeoman and $W G V$ with $701.4,742.0$ and $752.0^{\circ} \mathrm{Cd}$, respectively. On the contrary, $E K G$ and $H$. Spat were the latest blooming genotypes with a thermal time needs $\left(1013.1\right.$ and $1018.4^{\circ} \mathrm{Cd}$, respectively) significantly higher than those necessary to other late flowering cultivars such as Perle and Redsell's Eastwell (986.4 and $993.7^{\circ} \mathrm{Cd}$, respectively). Omega and $H$. Mittlefruh performed as medium flowering cultivars showing a cumulative thermal time of 868.1 and $867.9^{\circ} \mathrm{Cd}$, respectively.

\section{Development of cones (growth stage $=71$ )}

The difference between the earliest and latest cultivar for cone formation date was $560.8^{\circ} \mathrm{Cd}$. $N B$ was again the earliest cultivar with a thermal time accumulation of $878.0^{\circ} \mathrm{Cd}$, significantly lower than those registered for other early cultivars such as Yeoman and Phoenix that accumulated 1002.1 and $1008.9^{\circ} \mathrm{Cd}$, respectively. On the contrary, we ranked Omega as one of the latest cone-developing genotype $\left(1418.9^{\circ} \mathrm{Cd}\right)$, just before $H$. Mittlefruh which accumulated $1438.8^{\circ} \mathrm{Cd}$ and was the last cultivar to get initial cone formation. Columbus, Challenger and $H$. Magnum performed as medium cultivars for this stage showing a thermal time need of $1184.2,1185.3$ and $1186.7^{\circ} \mathrm{Cd}$, respectively.

\section{Maturity of cones (growth stage $=89$ )}

The difference between the earliest and latest cultivar for harvest date was almost $500^{\circ} \mathrm{Cd}$. The earliest cultivar for this stage was Phoenix, which needed $2021.8^{\circ} \mathrm{Cd}$, a thermal time significantly lower than that necessary to the other early-maturing cultivar Cascade $\left(2099.3^{\circ} \mathrm{Cd}\right)$. Other cultivars showing precocity for cones ripening were H. Magnum, Yeoman and H. Tradition with 2142.0, 2143.9 and $2145.8^{\circ} \mathrm{Cd}$, respectively. On the contrary, H. Aroma, Omega, Fuggle and $H$. Spat performed as late-season genotypes and were harvested at 2451.0, 2467.6, 2485.3 and $2520.4^{\circ} \mathrm{Cd}$, respectively. $N B$ and $H$. Bitter accumulated 2301.3 and $2308.0^{\circ} \mathrm{Cd}$ to harvest, respectively and were both ranked as medium-ripening cultivars.

\section{Yield}

Significant variation in cone yield was found among tested cultivars (Table 3). Cascade, H. Magnum and Yeoman were the top performers during the whole study, reaching a 3 -year average production of 2.12, 1.22 and $1.11 \mathrm{t} \mathrm{ha}^{-1}$, respectively. In particular, it has to be noted that Cascade yielded significantly higher than H. Magnum and Yeoman in all growing seasons, even doubling their cone production level in 2014 and 2015. H. Spat ranked as fourth cultivar, yielding almost $0.9 \mathrm{t} \mathrm{ha}^{-1}(3-$ year mean). Averaged over three years, yields of the remaining cultivars were lower than $0.5 \mathrm{t} \mathrm{ha}^{-1}$, with Columbus, $H$. Aroma, NB, Perle and Pheonix never reaching $0.3 \mathrm{t} \mathrm{ha}^{-1}$. Averaged over tested varieties, yield was significantly higher in 2014 than those recorded in 2013 $(+23.5 \%)$ and $2015(+46.5 \%)$. Cultivars that showed yield significantly different across the years were those with medium to high 3 -years

Table 2. Thermal time $\left({ }^{\circ} \mathrm{Cd}\right)$ for sprouting, flowering, cones development and maturity, of the 20 cultivars under study.

\begin{tabular}{|c|c|c|c|c|}
\hline Cultivars & Sprouting & Flowering & Development of cones & Maturity of cones \\
\hline Cascade & 243.0 & 820.4 & 1040.0 & 2099.3 \\
\hline Challenger & 270.3 & 944.1 & 1185.3 & 2361.1 \\
\hline Columbus & 236.4 & 978.1 & 1184.2 & 2375.2 \\
\hline East Kent Golding & 377.9 & 1013.1 & 1345.0 & 2379.7 \\
\hline Fuggle & 320.8 & 903.3 & 1323.5 & 2485.3 \\
\hline Hallertau Mittlefruh & 296.4 & 867.9 & 1438.8 & 2366.7 \\
\hline Hallertauer Aroma & 327.6 & 901.9 & 1112.0 & 2451.0 \\
\hline Hallertauer Bitter & 366.1 & 772.5 & 1087.1 & 2308.0 \\
\hline Hallertauer Magnum & 258.3 & 928.9 & 1186.7 & 2142.0 \\
\hline Hallertauer Taurus & 321.3 & 981.3 & 1235.6 & 2231.4 \\
\hline Hallertauer Tradition & 350.1 & 907.4 & 1089.9 & 2145.8 \\
\hline Hallertauer Spat & 351.6 & 1018.4 & 1330.1 & 2520.4 \\
\hline Northern Brewer & 375.3 & 653.8 & 878.0 & 2301.3 \\
\hline Omega & 315.3 & 868.1 & 1418.9 & 2467.6 \\
\hline Perle & 395.4 & 986.4 & 1250.6 & 2386.0 \\
\hline Pheonix & 282.8 & 777.7 & 1008.9 & 2021.8 \\
\hline Redsell's Eastwell & 327.7 & 993.7 & 1324.1 & 2390.2 \\
\hline Tettnager & 351.5 & 701.4 & 1056.8 & 2337.6 \\
\hline Whitbread Golding Variety & 251.9 & 752.0 & 1066.5 & 2367.4 \\
\hline Yeoman & 286.4 & 742.0 & 1002.1 & 2143.9 \\
\hline LSD $(\mathrm{P}<0.05)$ & 6.4 & 5.7 & 6.5 & 6.7 \\
\hline LSD $(\mathrm{P}<0.01)$ & 8.5 & 7.5 & 8.6 & 8.8 \\
\hline
\end{tabular}

LSD, least significant difference. 
average production level (more than $0.4 \mathrm{t} \mathrm{ha}^{-1}$ ). Conversely, no statistically significant results were detected over the years for the lowest yielding genotypes (9 out of 20).

The analysis of correlations among the studied parameters showed that yield was significantly influenced by heat accumulation to harvest (Table 4). In particular, the total increase of thermal time had a negative impact on the cone production $(\mathrm{r}=-0.5, \mathrm{P}<0.05)$.

\section{Plant growth}

Significant variation in plant growth was observed among cultivars (Table 5). The high-yielding cultivars Cascade, H. Magnum, H. Spat and Yeoman were also the tallest ones in all three years, ranging between 4.6 and $6 \mathrm{~m}$. Significant positive correlation $(\mathrm{r}=0.56, \mathrm{P}<0.05)$ was found between cone yield and plant height (Table 4). Cultivars Redsell's Eastwell and H. Taurus performed similarly to the previous group but they were not equally productive. Columbus, EKG and Perle were the shortest cultivars, never reaching height of $4 \mathrm{~m}$.

\section{Sensory analysis}

Results showed significant sensory differences among the beer samples in this study (Table 6). In general, the attributes of higher intensity recorded in the tested beers were: bitter, sapid, fruity, flowery, herby and spicy. Samples of beers produced with local cones were significantly bitterer as compared to commercials and control, with the exception of $H$. Spat hopped beer. Similarly, beers flavoured with local cones obtained scores markedly higher than commercial ones both in flowery and herby attributes, with the exception of $E K G$, which was not statistically different in herby taste. Moderate but not significant increase in spicy attribute was found for cv $H$. Tradition, $H$. Spat and EKG vs control, while local Cascade had significant higher score in the same taste. Moreover, local beers showed values significantly higher than commercial ones and control in sapid and pungent attributes when flavoured with Cascade and Fuggle, respectively. Columbus, Yeoman and Omega, have not had a corresponding commercial sample so they were compared to the other local cultivars. Specifically, Columbus showed a strong enhancement for the floral and fruity flavour, while Yeoman and Omega, increased the bitter taste and slightly the floral and grassy sensorial perception as compared to the control.

\section{Discussion}

\section{Crop phenology}

Plant development and thus phenological phases showed a significant difference among tested cultivars. This finding was due to the extreme heterogeneity in plant material as it consists of genotypes having different origins, background and maturity timelines. Generally, our results on hop precocity, or time to flowering, were consistent with information provided by hop nursery's varietal guide with the exception of $H$. Aroma and $E K G$, which we ranked as medium and late cultivars, respectively. Considering the hop growing period (from sprouting to maturity of cones), we found thermal time ranging between $1739^{\circ} \mathrm{Cd}$ of early-maturing cv Pheonix and $2168.8^{\circ} \mathrm{Cd}$ of late-maturing cv H. Spat. Similarly Srečec et al. $(2008,2013)$, recorded an average heat accumulation of $1800^{\circ} \mathrm{Cd}$ during a six-years study (2001-2006) in Croatia (latitude: $4601^{\prime} 51$ ' N) and $1766.2^{\circ} \mathrm{Cd}$ in Slovenia (latitude: 4615 ' 13" N) in 2012 for the medium-early cultivar Aurora.

\section{Yield}

In our study, cultivar per year interaction significantly affected hop production. Several authors highlighted the importance of yearly climatic pattern in determining an adequate growth, yield and quality for different hop cultivars (Bavec et al., 2003; Srečec et al., 2004, 2008; Pavlovic et al., 2012, 2013).

Table 3. Cones yield $\left(\mathrm{t} \mathrm{ha} \mathrm{h}^{-1}\right.$ ) of cultivars under study during 2013-2015 growing seasons.

\begin{tabular}{lcccc} 
Cultivar & 2013 & 2014 & 2015 & Mean \\
Cascade & 1.98 & 2.62 & 1.78 & 2.12 \\
Challenger & 0.38 & 0.49 & 0.17 & 0.35 \\
\hline Columbus & 0.30 & 0.21 & 0.26 & 0.26 \\
East Kent Golding & 0.26 & 0.27 & 0.22 & 0.25 \\
\hline Fuggle & 0.30 & 0.47 & 0.27 & 0.34 \\
Hallertau Mittlefruh & 0.38 & 0.41 & 0.36 & 0.38 \\
\hline Hallertauer Aroma & 0.19 & 0.12 & 0.16 & 0.15 \\
Hallertauer Bitter & 0.35 & 0.37 & 0.30 & 0.34 \\
\hline Hallertauer Magnum & 1.25 & 1.45 & 0.97 & 1.22 \\
Hallertauer Taurus & 0.40 & 0.64 & 0.33 & 0.45 \\
\hline Hallertauer Tradition & 0.46 & 0.60 & 0.32 & 0.46 \\
Hallertauer Spat & 0.81 & 1.04 & 0.75 & 0.87 \\
\hline Northern Brewer & 0.17 & 0.14 & 0.15 & 0.15 \\
Omega & 0.43 & 0.41 & 0.40 & 0.41 \\
\hline Perle & 0.19 & 0.13 & 0.16 & 0.16 \\
Pheonix & 0.19 & 0.26 & 0.18 & 0.21 \\
\hline Redsell's Eastwell & 0.43 & 0.60 & 0.33 & 0.45 \\
Tettnager & 0.37 & 0.56 & 0.29 & 0.41 \\
\hline Whitbread Golding Variety & 0.34 & 0.42 & 0.28 & 0.35 \\
Yeoman & 1.11 & 1.34 & 0.88 & 1.11 \\
\hline LSD (P<0.05) & & 0.12 & & 0.07 \\
LSD (P<0.01) & & 0.16 & & 0.09 \\
\hline SD, & & &
\end{tabular}

LSD, least significant difference for Cultivar $\times$ Year interaction and mean value.

Table 4. Pearson's correlation coefficients between cone yield, plant height and thermal time to flowering, cone development and maturity, averaged over three growing seasons.

\begin{tabular}{lccccc} 
& Cone yield & Height & Tt to flowering & Tt to cones development & Tt to cones maturity \\
Cone yield & 1 & $0.557^{*}$ & -0.284 & -0.323 & $-0.500^{*}$ \\
Height & - & 1 & -0.259 & -0.129 & -0.330 \\
\hline Tt to flowering & - & - & 1 & $0.788^{* *}$ & 0.303 \\
Tt to cones development & - & - & - & - & $0.491^{*}$ \\
\hline Tt to cones maturity & - & - & - & 1 & 1 \\
\hline
\end{tabular}

Tt, thermal time. ${ }^{*} \mathrm{P}<0.05 ;{ }^{*} \mathrm{P}<0.01$. 
Cones production and its qualitative features were largely determined by weather factors such as air temperature and rainfall (Mozny et al., 2009). In the present study, the highest yielding year was 2014 because of the favourable climatic conditions (without extreme heat events) registered from mid-June to late July: average temperatures between 20 and $22^{\circ} \mathrm{C}$ and more than $210 \mathrm{~mm}$ of total rainfall. In that period all cultivars were developing the reproductive stages of blooming and cone formation, which are fundamental phenological phases in determining final yield and production quality (Kucera and Krofta, 2009; Pokorný et al., 2011; Potop, 2014). This is confirmed by our observation during cultivars reproductive growth occurred in the following driest year. In 2015, indeed, average temperatures varied between $20.7^{\circ} \mathrm{C}$ in mid-June to $27.2^{\circ} \mathrm{C}$ in mid-July with a total rainfall amount of just $41 \mathrm{~mm}$. Moreover, maximum temperatures in July were even higher than $34^{\circ} \mathrm{C}$ with no precipitation from the third decade of June to the second decade of July. This protracted and intense drought probably caused higher percentage of floret abortion and cones formation on the lower insertion of hop plants (Srečec et al., 2004), determining severe reduction in cone yield (Ceh et al., 2012), especially for late maturing cultivars such as Challenger (-64.2\%), H. Magnum (-33.3\%), H. Spat $(-28 \%)$ and $H$. Taurus $(-48.6 \%)$. Furthermore, the significant decrease in cone yield which affected more than 50\% of tested cultivars in 2015 confirmed results by Srečec et al. (2008), who found a negative correlation $\left(\mathrm{r}_{s}=-0.75, \mathrm{P}<0.05\right)$, during the growth stage of cones formation, between average daily reference crop evapotranspiration in July and final cone yield.

\section{Plant growth}

Cultivar per year interaction significantly influenced final plants height. Hop growth dynamics were regular in 2013 and 2014 growing season thanks to the optimal weather conditions registered in April and May when the most intensive hop growth occurred. Conversely, rela-
Table 5. Plant annual and average height (m) reached by cultivars during 2013-2015 growing seasons.

\begin{tabular}{lcccc} 
Cultivars & 2013 & 2014 & 2015 & Mean \\
Cascade & 6.00 & 6.00 & 5.23 & 5.74 \\
Challenger & 6.00 & 5.74 & 3.74 & 5.16 \\
\hline Columbus & 3.64 & 2.83 & 2.00 & 2.82 \\
East Kent Golding & 4.00 & 3.94 & 1.97 & 3.30 \\
\hline Fuggle & 5.93 & 4.57 & 3.22 & 4.57 \\
Hallertau Mittlefruh & 6.00 & 5.80 & 4.82 & 5.54 \\
\hline Hallertauer Aroma & 6.00 & 5.80 & 4.38 & 5.39 \\
Hallertauer Bitter & 6.00 & 5.84 & 4.42 & 5.42 \\
\hline Hallertauer Magnum & 6.00 & 5.80 & 4.61 & 5.47 \\
Hallertauer Taurus & 5.00 & 6.00 & 4.84 & 5.28 \\
\hline Hallertauer Tradition & 6.00 & 5.70 & 4.16 & 5.29 \\
Hallertauer Spat & 6.00 & 6.00 & 4.88 & 5.63 \\
\hline Northern Brewer & 4.44 & 4.15 & 3.50 & 4.03 \\
Omega & 5.80 & 5.70 & 3.65 & 5.05 \\
\hline Perle & 3.64 & 3.61 & 3.31 & 3.52 \\
Pheonix & 6.00 & 5.70 & 4.23 & 5.31 \\
\hline Redsell's Eastwell & 5.40 & 6.00 & 4.79 & 5.40 \\
Tettnager & 5.70 & 6.00 & 4.14 & 5.28 \\
\hline Whitbread Golding Variety & 5.70 & 5.62 & 3.73 & 5.02 \\
Yeoman & 6.00 & 6.00 & 4.82 & 5.61 \\
\hline LSD (P<0.05) & & 0.58 & & 0.33 \\
LSD (P<0.01) & & 0.76 & & 0.44 \\
\hline
\end{tabular}

LSD, least significant difference for Cultivar $\times$ Year interaction and mean value.

Table 6. Mean scores obtained in sensory analysis by beers dry hopped with local and commercial cones and by control.

\begin{tabular}{|c|c|c|c|c|c|c|c|c|c|c|}
\hline Attributes & Hop & Cascade & Columbus & $\begin{array}{l}\text { East Kent } \\
\text { Golding }\end{array}$ & Fuggle & $\begin{array}{c}\text { Hallertauer } \\
\text { Tradition }\end{array}$ & $\begin{array}{c}\text { Hallertauer } \\
\text { Spat }\end{array}$ & Omega & Yeoman & Control \\
\hline Sweet & $\begin{array}{l}\mathrm{L} \\
\mathrm{C}\end{array}$ & $\begin{array}{l}1.00^{\mathrm{b}} \\
2.33^{\mathrm{a}}\end{array}$ & $\begin{array}{c}1.00^{\mathrm{b}} \\
-\end{array}$ & $\begin{array}{l}1.00^{\mathrm{b}} \\
1.67^{\mathrm{ab}}\end{array}$ & $\begin{array}{l}1.00^{\mathrm{b}} \\
1.67^{\mathrm{ab}}\end{array}$ & $\begin{array}{l}1.00^{\mathrm{b}} \\
1.33^{\mathrm{b}}\end{array}$ & $\begin{array}{l}1.00^{\mathrm{b}} \\
1.00^{\mathrm{b}}\end{array}$ & $\begin{array}{c}1.67^{\mathrm{ab}} \\
-\end{array}$ & $\begin{array}{c}1.33^{\mathrm{b}} \\
-\end{array}$ & $1.00^{\mathrm{b}}$ \\
\hline Bitter & $\begin{array}{l}\mathrm{L} \\
\mathrm{C}\end{array}$ & $\begin{array}{l}4.67^{\mathrm{bd}} \\
2.33^{\mathrm{f}}\end{array}$ & $\begin{array}{c}4.00^{\text {de }} \\
-\end{array}$ & $\begin{array}{l}5.33^{\mathrm{b}} \\
3.67^{\mathrm{e}}\end{array}$ & $\begin{array}{l}6.67^{\mathrm{a}} \\
2.67^{\mathrm{f}}\end{array}$ & $\begin{array}{l}4.00^{\text {de }} \\
2.33^{f}\end{array}$ & $\begin{array}{l}5.00^{\mathrm{bc}} \\
6.67^{\mathrm{a}}\end{array}$ & $\begin{array}{c}5.00^{\mathrm{bc}} \\
-\end{array}$ & $\begin{array}{c}4.33^{c e} \\
-\end{array}$ & $2.67^{\mathrm{f}}$ \\
\hline Sapid & $\begin{array}{l}\mathrm{L} \\
\mathrm{C}\end{array}$ & $\begin{array}{l}4.33^{\mathrm{a}} \\
3.00^{\mathrm{bd}}\end{array}$ & $\begin{array}{c}4.67^{\mathrm{a}} \\
-\end{array}$ & $\begin{array}{l}2.00^{\mathrm{d}} \\
2.00^{\mathrm{d}}\end{array}$ & $\begin{array}{l}3.67^{\mathrm{ac}} \\
4.00^{\mathrm{ab}}\end{array}$ & $\begin{array}{l}2.00^{\mathrm{d}} \\
2.33^{\mathrm{d}}\end{array}$ & $\begin{array}{l}3.00^{\text {bd }} \\
2.67 \text { cd }\end{array}$ & $\begin{array}{c}3.67^{\mathrm{ac}} \\
-\end{array}$ & $\begin{array}{c}2.33^{\mathrm{d}} \\
-\end{array}$ & $2.33^{\mathrm{d}}$ \\
\hline Astringent & $\begin{array}{l}\mathrm{L} \\
\mathrm{C}\end{array}$ & $\begin{array}{l}1.67^{a c} \\
0.00^{c}\end{array}$ & $\begin{array}{c}1.00^{\mathrm{ac}} \\
-\end{array}$ & $\begin{array}{l}1.33^{\mathrm{ac}} \\
2.33^{\mathrm{a}}\end{array}$ & $\begin{array}{l}2.00^{a b} \\
0.00^{c}\end{array}$ & $\begin{array}{l}2.00^{a b} \\
0.67^{a c}\end{array}$ & $\begin{array}{l}1.00^{\mathrm{ac}} \\
0.33^{\mathrm{bc}}\end{array}$ & $\begin{array}{c}1.00^{\mathrm{ac}} \\
-\end{array}$ & $\begin{array}{c}0.67^{a c} \\
-\end{array}$ & $0.33^{b c}$ \\
\hline Pungent & $\begin{array}{l}\mathrm{L} \\
\mathrm{C}\end{array}$ & $\begin{array}{l}1.33^{\mathrm{bc}} \\
0.33^{\mathrm{bc}}\end{array}$ & $\begin{array}{c}0.67^{\mathrm{bc}} \\
-\end{array}$ & $\begin{array}{l}2.00^{\mathrm{b}} \\
0.00^{\mathrm{c}}\end{array}$ & $\begin{array}{l}4.00^{\mathrm{a}} \\
0.33^{\mathrm{bc}}\end{array}$ & $\begin{array}{l}1.67^{\mathrm{bc}} \\
0.33^{\mathrm{bc}}\end{array}$ & $\begin{array}{l}1.67^{\mathrm{bc}} \\
0.67^{\mathrm{bc}}\end{array}$ & $\begin{array}{c}0.33^{\mathrm{bc}} \\
-\end{array}$ & $\begin{array}{c}2.00^{\mathrm{b}} \\
-\end{array}$ & $1.67^{\mathrm{bc}}$ \\
\hline Acid & $\begin{array}{l}\mathrm{L} \\
\mathrm{C}\end{array}$ & $\begin{array}{l}1.33^{\mathrm{ab}} \\
0.00^{\mathrm{c}}\end{array}$ & $0.00^{c}$ & $\begin{array}{l}2.00^{\mathrm{a}} \\
0.67^{\mathrm{bc}}\end{array}$ & $\begin{array}{l}0.67^{\mathrm{bc}} \\
0.00^{\mathrm{c}}\end{array}$ & $\begin{array}{l}1.33^{\mathrm{ab}} \\
0.00^{\mathrm{c}}\end{array}$ & $\begin{array}{l}1.33^{\mathrm{ab}} \\
2.00^{\mathrm{a}}\end{array}$ & $\begin{array}{c}1.33^{\mathrm{ab}} \\
-\end{array}$ & $\begin{array}{c}0.00^{c e} \\
-\end{array}$ & $1.00^{a c}$ \\
\hline Floral & $\begin{array}{l}\mathrm{L} \\
\mathrm{C}\end{array}$ & $\begin{array}{l}4.00^{\mathrm{b}} \\
2.67^{\mathrm{ce}}\end{array}$ & $\begin{array}{c}5.67^{\mathrm{a}} \\
-\end{array}$ & $\begin{array}{l}2.67^{\mathrm{ce}} \\
1.33^{\mathrm{f}}\end{array}$ & $\begin{array}{l}3.67^{\mathrm{bc}} \\
2.33^{\mathrm{df}}\end{array}$ & $\begin{array}{l}1.67^{\mathrm{ef}} \\
0.00^{\mathrm{g}}\end{array}$ & $\begin{array}{c}3.67^{\mathrm{bc}} \\
1.33^{\mathrm{f}}\end{array}$ & $3.00^{\text {bd }}$ & $\begin{array}{c}4.00^{\mathrm{b}} \\
-\end{array}$ & $1.33^{\mathrm{f}}$ \\
\hline Fruity & $\begin{array}{l}\mathrm{L} \\
\mathrm{C}\end{array}$ & $\begin{array}{l}3.33^{\mathrm{ad}} \\
2.33^{\mathrm{cd}}\end{array}$ & $\begin{array}{c}5.33^{\mathrm{a}} \\
-\end{array}$ & $\begin{array}{l}5.00^{\mathrm{ab}} \\
2.00^{\mathrm{cd}}\end{array}$ & $\begin{array}{l}2.33^{\text {cd }} \\
3.67^{\text {ad }}\end{array}$ & $\begin{array}{l}4.00^{\mathrm{ac}} \\
1.67^{\mathrm{d}}\end{array}$ & $\begin{array}{l}2.33^{\text {cd }} \\
2.00^{\text {cd }}\end{array}$ & $\begin{array}{c}3.67^{\mathrm{ad}} \\
-\end{array}$ & $\begin{array}{c}3.00^{\mathrm{bd}} \\
-\end{array}$ & $2.67^{\mathrm{cd}}$ \\
\hline Grassy & $\begin{array}{l}\mathrm{L} \\
\mathrm{C}\end{array}$ & $\begin{array}{l}4.67^{\mathrm{ac}} \\
1.00^{\mathrm{g}}\end{array}$ & $\begin{array}{c}4.33^{\mathrm{bd}} \\
-\end{array}$ & $\begin{array}{l}5.67^{\mathrm{a}} \\
5.00^{\mathrm{ab}}\end{array}$ & $\begin{array}{l}3.67^{\mathrm{ce}} \\
1.67^{\mathrm{fg}}\end{array}$ & $\begin{array}{l}2.67^{\mathrm{ef}} \\
1.00^{\mathrm{g}}\end{array}$ & $\begin{array}{l}4.00^{\mathrm{cd}} \\
2.00^{\mathrm{fg}}\end{array}$ & $\begin{array}{c}3.33^{\mathrm{de}} \\
-\end{array}$ & $\begin{array}{c}3.67^{\mathrm{ce}} \\
-\end{array}$ & $2.67^{\mathrm{ef}}$ \\
\hline Spicy & $\begin{array}{l}\mathrm{L} \\
\mathrm{C}\end{array}$ & $\begin{array}{l}4.67^{\mathrm{a}} \\
3.67^{\mathrm{ab}}\end{array}$ & $\begin{array}{c}1.00^{c} \\
-\end{array}$ & $\begin{array}{l}3.67^{\mathrm{ab}} \\
4.00^{\mathrm{ab}}\end{array}$ & $\begin{array}{l}2.33^{b c} \\
2.33^{b c}\end{array}$ & $\begin{array}{l}3.67^{\mathrm{ab}} \\
3.67^{\mathrm{ab}}\end{array}$ & $\begin{array}{l}3.67^{\mathrm{ab}} \\
3.33^{\mathrm{ab}}\end{array}$ & $2.00^{\mathrm{b}}$ & $\begin{array}{c}4.00^{\mathrm{ab}} \\
-\end{array}$ & $2.33^{\mathrm{bc}}$ \\
\hline
\end{tabular}

$\mathrm{L}$, local; C, commercial. ${ }^{\mathrm{a}-\mathrm{g}}$ For each attribute means followed by the same letters are not statistically different $(\mathrm{P}<0.05)$. 
tively high temperatures and poor rainfall in April and May 2015 (average temperature $15.0^{\circ} \mathrm{C}$ and only $20.0 \mathrm{~mm}$ of rainfall) caused an early start of the reproductive phase and, as a consequence, plants stopped growing. This finding is consistent with results by Srečec et al. (2004) who attributed low cone yield in 2003 to the irregular growth of plants connected with mild average temperatures $\left(10.3^{\circ} \mathrm{C}\right)$ and low rainfall ( $22.4 \mathrm{~mm}$ ) at the beginning of April.

\section{Sensory analysis}

Concerning the differences in flavour found in beers hopped with local and commercial cones, it is arguable that growing area affects sensory perception of beer. In particular, bitter, flowery and herby attributes, more than the others, seem to be influenced by hopping beer with local cones. Other studies demonstrated that cones of the same cultivars from different localities had different organoleptic profiles (Green, 1997; Kishimoto et al., 2008). In particular, Jelinek et al. (2012) pinpointed that drier and warmer growing areas produced hops with higher secondary metabolites content such as $\alpha$ - and $\beta$-bitter acids, essential oils, and polyphenols. These organic chemicals are commonly employed in brewing process and it is known that polyphenols are highly flavour-active compounds, with positive effects on mouthfeel (Goiris et al., 2014). This can explain why the beers dryhopped with local cones generally had more intense flavour as compared to commercial ones and higher perception of astringency and bitterness (Mikyska et al., 2002; Aron and Shellhammer, 2010).

\section{Conclusions}

There was a big difference among cultivars for maturity timelines, plant height, cone yield, and beer quality. Hop growth and yield were significantly affected by yearly weather conditions. Particularly stress due to the shortage of rainfall and high temperatures, especially during flowering and cones formation, have had negative effect on plants growth and cones yield. Four cultivars (Cascade, H. Magnum, H. Spat and Yeoman) showed good yield performance under climatic condition of Central Italy and might be better explored in the future either to evaluate their drought and pest tolerance or the influence of different agronomic techniques on cones production and quality traits. With regard to beer quality, the results of the sensory analysis showed a more complex and appreciated profile for beers flavoured with local cones than those hopped with commercial products. These interesting results suggest the need to further investigate the effect of the growing area on hops quality and beer organoleptic properties. This study represents a first step to face challenges and opportunities for hop production in Central Italy and highlights the need for a screening of wild Italian genotypes to start hop breeding programs.

\section{References}

Aron PM, Shellhammer TH, 2010. A discussion of polyphenols in beer physical and flavour stability. J. Inst. Brew. 116:369-80.

ASBC (American Society of Brewing Chemists), 2009. The science of beer. Available from: http://www.asbcnet.org/store/Pages/ WHEEL1.aspx

Assobirra, 2009. Annual Report for the year 2008. Available from: www.assobirra.it

Assobirra, 2014. Annual Report 2014. Available from: www.assobirra.it Bavec F, ČehBrežnik B, Brežnik M, 2003. Hop yield evaluation depend- ing on experimental plot area under different nitrogen management. Plant Soil Environ. 49:163-7.

Čeh B, Naglic B, Oset Luskar M, 2012. Hop (Humulus lupulus L.) cones mass and lenght at cv. Savinjski Golding. Hmeljar. Bilten/Hop Bull. 19:5-16.

Cerenak A, Satovic Z, Jakse J, Luthar Z, Carovic-Stanko K, Javornik B, 2009. Identification of QTLs for alpha acid content and yield in hop (Humulus lupulus L.). Euphytica 170:141-54.

Fandiño M, Olmedo JL, Martínez EM, Valladares J, Paredes P, Rey BJ, Mota M, Cancela JJ, Pereira LS, 2015. Assessing and modelling water use and the partition of evapotranspiration of irrigated hop (Humulus Lupulus), and relations of transpiration with hops yield and alpha-acids. Ind. Crop. Prod. 77:204-17.

Goiris K, Jaskula-Goiris B, Syryn E, Van Opstaele F, De Rouck G, Aerts G, De Cooman L, 2014. The flavoring potential of hop polyphenols in beer. J. Am. Soc. Brew. Chem. 72:135-42.

Green CP, 1997. Comparison of Tettnanger, Saaz, Hallertau and Fuggle hops grown in the USA, Australia and Europe. J. Inst. Brew. 103:239-43.

Haunold A, 1980. Hop. In: W.R. Fehr, H.H. Hadley (Eds.), Hybridization of crop plants. American Society of Agronomy, Madison, WI, USA, pp 393-406.

Henning JA, Townsend MS, Gent DH, Bassil N, Matthews P, Buck E, Beatson R, 2011. QTL mapping of powdery mildew susceptibility in hop (Humulus lupulus L.). Euphytica 180:411-20.

International Olive Oil Council, 2007. Sensory analysis of olive oil standard glass for oil tasting. Available from: www.internationaloliveoil.org/documents/viewfile/3685-orga6

IS0 (International Organisation for Standardisation), 2007. IS0 8589:2007. Sensory analysis - General guidance for the design of test rooms. Available from: http://www.iso.org/iso/ catalogue_detail.htm?csnumber $=36385$

ISO (International Organisation for Standardisation), 2008. ISO 5492:2008. Sensory analysis - Vocabulary. Available from: http://www.iso.org/iso/catalogue_detail?csnumber $=38051$

ISO (International Organisation for Standardisation), 2016. ISO 13299:2016. Sensory analysis -Methodology - General guidance for establishing a sensory profile. Available from: http://www.iso.org/iso/catalogue_detail.htm?csnumber $=58042$

Jelinek L, Doleckova M, Karabin M, Hudcova T, Kotlikova B, Dostalek P, 2012. Influence of growing area, plant age, and virus infection on the contents of hop secondary metabolites. Czech J. Food Sci. 30:541-7.

Johnson DA, 1991. Two degree-day models for predicting initial emergence of hop shoots systemically infected with Pseudoperonospora humuli. Plant Dis. 75:285-7.

Kishimoto T, Kobayashi M, Yako N, Iida A, Wanikawa A, 2008. Comparison of 4-mercapto-4-methylpentan-2-one contents in hop cultivars from different growing regions. J. Agr. Food Chem. 56:1051-7.

Kucera J, Krofta K, 2009. Mathematical model for prediction of yield and alpha acid contents from meteorological data for Saaz aroma variety. Acta Hort. 848:131-9.

Mahaffee W, Pethybridge S, 2009. The genus Humulus. In: W.F. Mahaffee, S. Pethybridge, D.H. Gent (Eds.), Compendium of hop diseases and pests. The American Phytopathological Society, St. Paul, MN, USA, pp 1-5.

McAdam EL, Vaillancourt RE, Koutoulis A, Whittock SP, 2014. Quantitative genetic parameters for yield, plant growth and cone chemical traits in hop (Humulus lupulus L.). BMC Genet. 15:1-18.

McMaster GS, Wilhelm WW, 1997. Growing degree-days: one equation, two interpretations. Agr. Forest Meteorol. 87:291-300.

Meier U, 2001. Growth stages of mono-and dicotyledonousplants. BBCH 
Monograph. 2nd ed. Federal Biological Research Centre for Agriculture and Forestry, Berlin, Germany.

Mikyška A, Hrabák M, Hašková D, Šrogl J, 2002. The role of malt and hop polyphenols in beer quality, flavour and haze stability. J. Inst. Brew. 108:78-85.

Mongelli A, Rodolfi M, Ganino T, Marieschi M, Dall'Asta C, Bruni R, 2015. Italian hop germplasm: characterization of wild Humulus lupulus L. genotypes from Northern Italy by means of phytochemical, morphological traits and multivariate data analysis. Ind. Crops Prod. 70:16-27.

Mozny M, Tolasz R, Nekovar J, Sparks T, Trnka M, Zalud Z, 2009. The impact of climate change on the yield and quality of Saaz hops in the Czech Republic. Agr. Forest Meteorol. 149:913-9.

Murakami A, Darby P, Javornik B, Pais MSS, Seigner E, Lutz A, Svoboda P, 2006. Molecular phylogeny of wild hops, Humulus lupulus L. Heredity 97:66-74.

Patzak J, Nesvadba V, Henychová A, Krofta K, 2010. Assessment of the genetic diversity of wild hops (Humulus lupulus L.) in Europe using chemical and molecular analyses. Biochem. Syst. Ecol. 38:136-45.

Pavlovič M, Pavlovič V, Rozman Č, Udovč A, Stajnko D, Wang D, Gavric M, Srečec S, 2013. Market value assessment of hops by modeling of weather attributes. Plant Soil Environ. 59:267-72.

Pavlovič V, Pavlovič M, Čerenak A, Košir IJ, Čeh B, Rozman Č, Turk J, Pazek K, Krofta K, Gregorič G, 2012. Environment and weather influence on quality and market value of hops. Plant Soil Environ. 58:155-60.

Pignatti S, 1982. Flora d'Italia. Vol.1. Ed agricole, Bologna, Italy.

Potop V, 2014. The impact of dry and wet events on the quality and yield of Saazhops in the Czech hop growing regions. In: J. Rožnovský, T. Litschmann (Eds.), Mendel a bioklimatologie. Brno, Czech Republic, available from: http://www.cbks.cz/SbornikBrno
14/Potop_1.pdf

Pokorný J, Pulkrábek J, Štranc P, Bečka D, 2011. Photosynthetic activity of selected genotypes of hops (Humulus lupulus L.) in critical periods for yield formation. Plant Soil Environ. 57:264-70.

R Development Core Team, 2006. A language and environment for statistical computing, R Foundation for Statistical Computing, Vienna, Austria. Available from: http://www.R-project.org

Shishehgar R, Rezaie A, Nazeri M, 2012. Study of sedation, pre-anesthetic and anti-anxiety effects of hop (Humulus lupulus L.) extract compared with diazepam in rats. J. Anim. Vet. Adv. 11:2570-5.

Small E, 1978. A numerical and nomenclatural analysis of morpho-geographic taxa of Humulus. Syst. Bot. 3:37-76.

Srečec S, Kvaternjak I, Kaučić D, Marić V, 2004. Dynamics of hop growth and accumulation of $\alpha$-acids in normal and extreme climatic conditions. Agr. Conspec. Sci. 69:59-62.

Srečec S, Kvaternjak I, Kaučic D, Špoljar A, Erhatić R, 2008. Influence of climatic conditions on accumulation of alpha-acids in hop cones. Agric. Conspec. Sci. 73:161-6.

Srečec S, Čeh B, Ciler TS, Rus AF, 2013. Empiric mathematical model for predicting the content of alpha-acids in hop (Humulus lupulus L.) cv. Aurora. Springerplus 2:59.

Turner SF, Benedict CA, Darby H, Lori AH, Simonson P, Sirrine JR, Murphy KM, 2011. Challenges and opportunities for organic hop production in the United States. Agron. J. 103:1645-54.

Zanoli P, Zavatti M, 2008. Pharmacognostic and pharmacological profile of Humulus lupulus L. J. Ethnopharmacol. 116:383-96.

Zepp G, Smith S, Harwood J, 1995. Hops: an economic assessment of the feasibility of providing multiple-peril crop insurance - Prepared by the Economic Research Service, USDA, for the Consolidated Farm Service Agency, Office of Risk Management; July 26, 1995. Available from: http://www.rma.usda.gov/pilots/feasible/pdf/ hops.pdf 